\title{
Community engagement from the ground up: An interdisciplinary service-learning after-school garden program
}

\author{
Shari E. Miller, ${ }^{\mathrm{a}} *$ University of Georgia, School of Social Work \\ Jung Sun Lee, ${ }^{\mathrm{b}}$ University of Georgia, Foods and Nutrition \\ David Berle, ${ }^{c}$ University of Georgia, Horticulture
}

Submitted 5 January 2012 / Revised 29 March 2012 / Accepted 16 April 2012 / Published online 19 June 2012

Citation: Miller, S. E., Lee, J. S., Berle, D. (2012). Community engagement from the ground up: An interdisciplinary service-

learning after-school garden program. Journal of Agriculture, Food Systems, and Community Development, 2(3), 121-135.

http://dx.doi.org/10.5304/jafscd.2012.023.013

Copyright (C) 2012 by New Leaf Associates, Inc.

\begin{abstract}
Through the vehicle of community engagement, and with a commitment to ecological sustainability, the University of Georgia has made a series of efforts to support a growing local food movement through education, research, and service. This paper focuses on the development of a comprehensive after-school garden program with direct

\footnotetext{
a, * Shari E. Miller, Assistant Professor; BSW Program Director; School of Social Work; University of Georgia; 310 East Campus Road; Athens, GA 30602 USA; +1-706-5422328; semiller@uga.edu

b Jung Sun Lee, Assistant Professor; College of Family and Consumer Sciences; Foods and Nutrition; University of Georgia; 129 Barrow Hall; 115 DW Brooks Drive; Athens, GA 30602 USA; +1-706-542-6783; leejs@,fcs.uga.edu

${ }^{c}$ David Berle, Associate Professor; College of Agriculture and Environmental Sciences; Horticulture Department; University of Georgia; 1111 Plant Science Building; Athens, GA 30602 USA; +1-706-542-0771; dberle@uga.edu
}

links to the university via interdisciplinary servicelearning mechanisms. The university is located in a county with one of the highest poverty rates in the nation. With a commitment to creating innovative, community-empowered approaches to addressing poverty and related food insecurity, an interdisciplinary group of university faculty, in collaboration with community partners, came together to develop a sustainable after-school garden program. Students from three disciplines (foods and nutrition, horticulture, and social work) are placed in after-school sites to work with elementary school students to establish, support, and grow food gardens. This paper discusses the development process of the program. Anecdotal successes, challenges, and opportunities between, within, and across various systems are explored.

\section{Keywords}

community engagement, food insecurity, Higher Education Challenge Grant, interdisciplinary 
collaboration, local food systems, school gardens, service-learning, sustainability

\section{Introduction}

As colleges and universities across the United States are growing their ecological sustainability efforts, interdisciplinary collaboration and community engagement are becoming increasingly central to higher education initiatives, particularly at public institutions (Jones, 2003). In fact, the Carnegie Foundation has recently established a designation for "Community Engaged Institutions," a designation attained by schools that meet a rigorous set of criteria related to their reach into the community. These trends point to a movement grounded in the need to develop better relationships with resources, including how they are used and distributed, as well as how they are conserved. Built into this shift is the potential for university collaborations that cross disciplinary divides and create space for innovation. This paper presents the development and piloting of a multilayered community engaged program with an eye toward sustainability, with roots in a large public university housed in a county with one of the highest poverty rates in the nation. The project involved interdisciplinary collaboration among university faculty and students, the university's Office of Service Learning (OSL), and community partnerships with the county public school system and related stakeholders. The project was geared at developing a comprehensive after-school garden program with direct links to the university via service-learning mechanisms.

\section{Service-Learning}

Service-learning has been and continues to be a key component of the "higher education civic engagement movement" (Phillips, 2007, p. 4). It serves as a vehicle for colleges and universities to enhance their public service and community engagement efforts; successful service-learning structures rely on collaborative relationships between university and community with equity built into partnerships (Vernon \& Ward, 1999).

Because service-learning is a multidimensional process, establishing ways of measuring the process and its associated outcomes comprehensively has presented challenges for researchers (Gelmon,
2000). Measurement has tended to focus on one dimension of the process or on outcomes for one set of the multifaceted stakeholders (i.e., students, faculty, community partners, service recipients, etc.). According to an aggregate view of servicelearning in the higher education literature, servicelearning appears to be a highly effective experience for students, including outcomes associated with enhanced learning and academic success, personal and professional development, deepened sense of social responsibility, commitment to service, critical thinking, complexity of understanding, cognitive and moral development, and self-efficacy (Eyler, Giles, Stenson, \& Gray, 2003). Servicelearning outcomes for faculty include the positive increase in satisfaction related to student outcomes, enhancement of research agendas (Eyler et al.), and opportunities to apply theory and knowledge to solving local problems (Vernon \& Ward, 1999). Though, faculty also sight lack of reward for efforts and lack of resources as barriers to servicelearning efforts (Eyler et al.).

While service-learning is considered a primary means of creating a truly engaged campus, one that is not just physically located in a community but one that is "intimately connected to the public purposes and aspirations of community life itself" (Hollander, 1998, p. 3), very little research exists related to community partner outcomes (Vernon \& Ward, 1999).The school garden program, by design, sought to fully integrate the community partner, and as such, research efforts will attempt to comprehensively evaluate outcomes across all stakeholders: students, faculty, program participants, and administrative and community structures.

\section{School Gardens}

According to Blair (2009), over the past two decades, school gardening has become a "national movement" that includes planned curricula and evaluative research in some states, and programs promoting school gardening in others. Generally, gardening curricula and programming tend to be designed primarily for elementary-age students, and the noted purposes of school garden efforts focus on academic, behavioral, recreational, social, political, and environmentally remediating variables (Blair). Given the nature of contemporary U.S. 
culture, media, video games, and organized sports have largely replaced children's opportunities to explore, in an uncontained way, their natural environments (Moore, 1995). Children's environments are where they develop their imaginations and their sense of the world around them (Mergen, 2003). Media and formal playgrounds may delimit children's natural experiences, but "well-designed school gardens can readily improve on the complexity of that experience and provide the repetitive access, meanings, and associations needed to create a bond with a place" (Blair, 2009, p. 17).

According to quantitative research, some positive outcomes of school garden programs include increased knowledge about food systems (Graham, Feenstra, Evans, \&Zidenberg-Cherr, 2004; Morris, Briggs, \&Zidenberg-Cherr, 2000; Rahm, 2002), improvement in science achievement (Dirks \& Orvis, 2005; Klemmer, Waliczek, \&Zajicek, 2005; Mabie\& Baker, 1996; Smith $\&$ Mostenbocker, 2005), and improvement in nutrition knowledge and preference for fruit and vegetables (Lineberger \& Zajicek, 2000; McAleese\& Rankin, 2007; Morris \& ZidenbergCherr, 2002; Parmer, Salisbury-Glennon, Shannon, \&Struempler, 2009). According to Blair (2009), findings from the body of qualitative research capture some social outcomes and include students' excitement and motivation around gardening, being outside, and getting dirty; improved attitude about school and a sense of pride related to their gardens and harvest; and community-building components.

Most formal school garden efforts and their related research focus on the integration of the garden into the extant curricula, with a link to performance standards. The after-school garden program discussed in this paper was designed to create opportunities for students and the community to engage with the environment and to approach the idea of sustainability through activities and programs that were not confined to curricular requirements and performance standards, but instead linked to what comes after and outside the school day. In addition, the bulk of the extant literature focuses particularly on nutritional, health, and educational outcomes associated with school gardens, with little systematic research focused on psychosocial and community outcomes. This afterschool garden program was designed with the hope of extending the school garden into the community; the long-range goals of the program emphasize a shift in children's and the community's relationship to place, to the environment, to nutrition, to where food comes from, to self- and collective-efficacy, and to sustainability.

\section{Context of Place}

\section{University of Georgia}

The University of Georgia (UGA) was incorporated in 1785 and officially established in 1801 (Office of Public Affairs, n.d. a). According to its mission, UGA is"a land-grant and sea-grant university with statewide commitments and responsibilities, [and] is the state's oldest, most comprehensive, and most diversified institution of higher education. Its motto, 'to teach, to serve, and to inquire into the nature of things,' reflects the University's integral and unique role in the conservation and enhancement of the state's and nation's intellectual, cultural, and environmental heritage" (Office of Public Affairs, n.d. b, para. 1). Given its long history in and commitment to the state and local community, UGA has a longstanding relationship to the idea of "place."

As a land-grant institution, UGA extends its reach directly into the community of which it is a part, as well as outside those boundaries to the state of Georgia and beyond. UGA was recently "recognized by the Carnegie Foundation for its institutional commitment to community engagement through teaching, research, and public service with the Community Engagement Classification," making it one of only 311 institutions nationally to hold this distinction (Matthews, 2011). While the university has a clear and long-established relationship to its "place," that relationship and the university's efforts to address the needs of its place shift in response to prevailing social and ecological concerns.

\section{Athens-Clarke County}

UGA is housed in Athens-Clarke County (ACC); ACC is a unified city/county located in northeast Georgia, approximately 70 miles $(113 \mathrm{~km})$ east of 
Atlanta. As of the 2010 U.S. census, ACC had a total of 116,714 residents. Approximately 62 percent of the ACC population is White, 26.6 percent is African American, and 10.4 percent is Hispanic or Latino (U.S. Census Bureau, n.d.). ACC is one of the poorest counties in the nation; the unemployment rate in ACC of 8.0 percent in September 2011 is lower than the Georgia and national averages (10.3 percent and 9.1 percent, respectively) (Georgia Department of Labor, n.d.). The ACC poverty rate of 36.7 percent, however, is more than twice the Georgia and national rates (17.9 percent and 15.3 percent, respectively) (U.S. Census Bureau, n.d.). Poverty differentially affects ACC residents with various racial and ethnic backgrounds at a variety of life stages. Those more likely to live in poverty than other groups in ACC include families with children under 18 years old (23.8 percent), especially families with female householders with children under five years of age (43.6 percent), as well as African Americans and Hispanics (U.S. Census Bureau). Children in particular are disproportionately affected by poverty in ACC; 40.9 percent of residents under 18 years old live in poverty compared to the state and national rates of 24.8 percent and 21.6 percent, respectively (U.S. Census Bureau).

The higher burden of poverty in ACC suggests that many residents are at risk of food insecurity, defined generally as "limited or uncertain availability of nutritionally adequate and safe foods or limited, or uncertain ability to acquire acceptable foods in socially acceptable ways" (Anderson, 1990, p.1576). More than one out of every five (21.0 percent) ACC residents are food insecure, higher in comparison to state and national averages (17.8 percent and 16.6 percent, respectively) (Feeding America, 2010). About 61 percent of ACC residents are eligible for the Supplemental Nutrition Assistance Program (SNAP, formerly food stamps) (Feeding America). The total SNAP benefits distributed to ACC residents were nearly USD15 million in 2008 (U.S. Department of Agriculture, n.d. a). Parallel to the trend in poverty, children in ACC are at a significantly higher risk of food insecurity (29.2 percent), and more than 70 percent of them are in households that are income-eligible for federal nutrition programs (Feeding America).
In 2008, nearly 70 percent of ACC school-age children were eligible for the free school lunch program and an additional 7 percent were eligible for the reduced school lunch program (U.S. Department of Agriculture, n.d. a). ACC residents received around 2.2 million meals from the Food Bank of Northeast Georgia (FBNG) in 2009 (Food Bank of Northeast Georgia, 2010).

Despite the attempts of the nation's federal and emergency food assistance programs, food insecurity is an enduring and growing problem in ACC due to a history of persistent poverty, as well as the recent economic recession. The nation's food assistance programs are grounded in a model of social welfare that seeks to fill gaps in peoples' abilities to subsist on their own. FBNG (2010) reported a 30 percent increase from 2009 to 2010 in requests for emergency food boxes, and waiting lists for federally funded nutrition programs remain long. While the growing movement to expand local food systems in ACC is one focused on sustainability, there are questions about the degree to which the movement has effectively engaged those members of the community who are more likely to live in poverty and under food-insecure conditions.

The structural and institutional issues that have bearing on people's access to affordable, healthy food may contribute to food insecurity. Based on a new definition of a food desert by the U.S. departments of Agriculture, Treasury, and Health and Human Services (i.e., a census tract with "a substantial share of residents who live in low-income areas that have low levels of access to a grocery store or healthy affordable food retail outlet" (U.S. Department of Agriculture, Agricultural Marketing Service, n.d., para. 1)), 11 out of 29 census tracts in ACC are classified as food deserts (U.S. Department of Agriculture, n.d. b). A total of 6,636 residents living in these census tracts in ACC have low access to a supermarket or large grocery store, and 65.4 percent of those are under the age of 18 (U.S. Department of Agriculture, n.d. b). Preliminary findings from the Athens Food Policy Council Food Store Audit Study (Lee, Bender, Kurtz, \& $\mathrm{Kim}$, in press) showed that many food stores in ACC did not carry a variety of healthy and afford- 
able foods that would allow low-income residents to follow USDA's Thrifty Food Plan (TFP). ${ }^{1}$ On average, only 67 percent of food items needed to prepare a TFP-based regional weekly menu was available in the selected supermarkets and grocery stores. The three most frequently missing food groups were fresh fruits and vegetables and frozen vegetables. The cost of purchasing groceries for the weekly TFP menu in ACC was 46.3 percent higher than that of the U.S. average in November 2008 (Lee et al., in press).

With rising food prices and the continuing economic recessions, food-insecure ACC residents, especially children, will face continued challenges around having consistent and dependable access to enough food for active and healthy living. The need is becoming increasingly urgent to identify sustainable, empowering strategies to increase access to healthy foods for people at all income levels, and to pay particular heed to reaching people who are living in poverty and are food insecure.

\section{Local Food Movement at the UGA}

At the beginning of the 2009-2010 academic year the OSL convened a series of meetings between community partners and university faculty and staff to better coordinate efforts to effect change in the local food system. The consensus from those meetings was to harness collective efforts to collaborate between the many departments on campus with an interest in local foods and the various community agencies with an agenda that includes sustainability, food, nutrition, or gardening. One result of those meetings was the decision to submit a proposal to the USDA National Institute of Food and Agriculture (NIFA) for a Higher Education Challenge Grant to develop a certificate in local food systems. The proposal included plans to establish a student-run demonstration garden in addition to an interdisciplinary certificate program.

1 The USDA Thrifty Food Plan, which is the foundation for SNAP (http://www.cnpp.usda.gov/USDAFoodPlans CostofFood.htm), provides a national standard for a nutritious and affordable diet specific to age and gender. See more at http://www.ers.usda.gov/Publications/ERR83/ERR83 $\underline{\text { AppC.pdf }}$
A second proposal was submitted to NIFA to create a community garden network to pull together scattered efforts to support local gardening projects. Both grants were awarded in the fall of 2010 .

The initial meetings and two grant projects resulted in the creation of a very active student-run garden project called UGArden. The garden covers approximately 1.5 acres ( 0.6 hectare) and, in addition to a large garden area, includes a composting program, a tilapia aquaponics demonstration, and a wood repurposing program. Three different courses are taught at the site. Approximately 4,000 pounds (1,814 kilograms) of fresh vegetables raised in the garden have been distributed during the 2012 growing season to local families in need through another student-run program called Campus Kitchen (a local chapter of a national organization of college students). The Campus Kitchen delivers meals and food on a regular basis to over 30 families in need through a local program called Grandparents Raising Grandchildren. The after-school gardening program emerged out of a shared commitment to address sustainability, poverty, and food insecurity among a variety of university faculty and community stakeholders.

\section{Development of the After-School Garden Program}

\section{Interdisciplinary Collaboration}

Given the size of UGA, with approximately 35,000 students, upwards of 2,800 faculty members, 3,900 administrative and other professionals (Office of Public Affairs, n.d. c), and the scope of university service activities and community engagement efforts, it stands to reason that a number of faculty, students, and staff share interests and commitments and may even be engaged in projects that are similar, yet are not aware of the efforts of others. One of the most powerful mechanisms for creating collaborative community engaged relationships between these many parties at UGA is the university's OSL. Through a variety of programs and efforts, including a Service-Learning Fellowship opportunity, the OSL works steadfastly to forge connections, promote collaboration, create positive, effective links between the university and 
the community, and creatively work to locate funds to support programs.

The OSL introduced the first author, who is on faculty in the School of Social Work and was a Service-Learning Fellow with a nebulous idea, to the third author, a faculty member from the Horticulture department who was pivotal to many of UGA's previously mentioned local foods and community garden efforts. The first author's interest stemmed from a commitment to expanding social work's definition of the "environment" beyond the social/human-constructed world to include a more ecologically just perspective that recognizes humans' relationship to nature, and focuses in on sustainability. In this vein, she was interested in creating a course for social work students that builds on social work's commitment to social justice, and to expand that definition to one that incorporates an environmentally and eventually ecologically just framework. It was her desire to do this with a built-in service-learning component that moved social work students out into the field in a way that was different from their required field internships in social service agencies. The objectives were to have social work students work with children in a school garden environment to enhance their understanding of the role of nature and ecology in the lives of their clients, to focus on issues of poverty and food insecurity with the county's children and families, to help children develop knowledge about where their food comes from and the role they can play in more sustainably producing and acquiring it, and to consider ways of engaging community members in these efforts. In developing an interdisciplinary collaboration with a faculty member from the Horticulture department, whose commitment to sustainable agriculture, local foods, and social justice led him to build and foster community garden efforts in a variety of areas in ACC, a nebulous idea became clearer and more grounded. With an interest in further building the nutrition and food security facets of the program, the second author from Foods and Nutrition was invited to collaborate, and eagerly agreed.

\section{Community Partners}

In the interest of inclusion, many people from multiple university departments (e.g., agricultural extension, education, foods and nutrition, geography, horticulture, public health, landscape and design, and social work to name some) and community stakeholders (e.g., ACC public school administrators, local non-profit administrators, active parent/teacher organization members) were invited to come together over the course of a semester and brainstorm about what school garden efforts were already being made and what might be useful next steps. The meetings were fruitful and yielded a strong commitment and a good deal of expressed interest from the ACC school officials to support the interdisciplinary efforts to create a systematic school garden program.

Out of these meetings came a clear sense that the most effective way to begin to establish this initiative would be through after-school programs. Given a series of identified obstacles, including curricular performance standards and resource issues, there was a good deal of support for the idea that an after-school program would have different kinds of freedoms than would a program initially structured to fit within extant science-based curriculum standards. In the interest of moving forward and to learn through doing, the collaborating faculty and community partners agreed to begin there, with a long-range plan to establish a garden-based structure and culture that potentially could be incorporated into the classroom as well. While meeting regularly was eminently helpful to the process, and essential to making key decisions, it became clear that in order to move forward, action would need to be taken. It was in that vein that the three faculty members who have written this paper decided to "dive in" and pilot some version of the program.

\section{Pilot Phases I and II}

Table 1 in the appendix shows the logic model that guided the development of the after-school garden program in the ACC. The program was initially piloted during spring 2011 semester, and the secondary pilot phase was completed during the fall 2011 semester. The following section describes the process of developing the program. The process of developing this program continues to be iterative, and in many ways is context-contingent; it is our hope that the following sections, along with 
the logic model, can serve as a guide and/or point of departure for others interested in developing similar programs at their colleges and universities.

\section{Establishing Sites}

In order to begin the program initially, the authors agreed to select five after-school locations. We used the following criteria to determine with which locations to pilot the program:(1) Does the school or site offer after-school programming? (2) Does the school or site have a Parent Teacher Organization (PTO), and to what degree is that structure active? (3) Does the school or site have a high percentage of children participating in free or reduced National School Lunch Program? (4) Does the school or site have any viable gardening space and/or any existing garden or garden structures? (5) Is the school or site accessible for UGA students who do not have cars and/or may not want to drive? (6) Do key school or site administrators have an interest in and willingness to participate in this program?

We used the above criteria in order to determine practical viability, and also to target schools or sites with the greatest levels of need. Once we ruled out schools without after-school programs, our next priority was to locate schools with the least active, least resource-rich, or nonexistent, Parent Teacher Organizations (PTO), with the idea being that the school garden program could provide resources, and if a PTO structure was not in place, it was highly likely that the families of the children at those schools were themselves functioning with fewer resources. Similarly, we attempted to target schools in the county that had higher percentages of children receiving supplemental food benefits. Then we considered the logistics regarding outdoor space and gardening structure and UGA student transportation and access. Lastly, and in some ways most instrumentally, we had to determine whether or not the administrators at particular schools were willing to consider our piloting the program with them. Working relationships between faculty and/or the OSL already existed with the administrators of some elementary schools, which helped to facilitate initial contact. In the event that working relationships did not already exist, faculty made contact and attempted to establish them. After a series of phone calls, emails, and meetings, we had arrived at our first set of five schools. For the second round, some of the sites remained as part of the pilot and others were substituted in order to troubleshoot, in some cases, and in other cases, in order to work toward expanding the program beyond five sites. For the spring semester, an afterschool program at a local chapter of the Boys and Girls Club was added. The eventual goal is for the program to be running in all after-school sites in ACC, including public schools and communitybased structures.

\section{Structure of the Service-Learning Interdisciplinary Program}

Students from the three disciplines (social work, horticulture, and foods and nutrition) were recruited to participate in the pilot. Their participation would involve a weekly three-hour service commitment, participation in weekly in-person interdisciplinary discussion groups, and use of an online learning platform to support reflective assignments. Students in social work would be enrolled in the new course being developed related to social work and eco-conscious, strengths-based practice, and students in horticulture and foods and nutrition would enroll in an existing Project FOCUS (Fostering Our Community's Understanding of Science) course designed to provide science teaching opportunities for non-education majors. The two courses entailed the same service commitment, but reflective assignments differed. The interdisciplinary service-learning component was designed to build on and draw from the skills and knowledge the students from each discipline contributed, but also to challenge students to bring different perspectives together to achieve common objectives. For both phases of the pilot, UGA students have contributed a great deal to the development of the program itself and to the development of the interdisciplinary components of the course. A series of intended and unintended learning opportunities were borne out of this collaborative structure, which will be discussed in greater detail in a later section of the paper.

Recruiting UGA Student Participants

Given the "dive-in" nature of the first pilot, time 
was relatively short, so faculty worked quickly and steadfastly to promote this opportunity to students in their respective disciplines. Students were contacted via departmental student listservs and provided with information about the opportunity to participate in a new interdisciplinary after-school garden program. Student responses to the initial recruitment efforts were profoundly positive; many more students were interested in participating than the capacity of the pilot would allow. Each student was contacted individually to determine commitment, availability, fit, and degree of interest. Given the substantial time commitment in terms of service hours, and the particular time-of-day requirements of the after-school structure, students' course schedules in some cases were prohibitive. Once the 15 students (five students from each of the three disciplines) were identified, their schedules were gathered. Out of the complex matrix of their available times, teams of three students each were established and assigned to a particular location. Students completed all necessary paperwork to receive legal clearance to be present on public school grounds and to work directly with elementary school students. For the second round of the pilot, students again were recruited via listservs, but word of mouth fueled additional student interest; based on the number of sites and the logistics of scheduling, 12 students (four students from each of the three disciplines) participated in the second pilot semester.

\section{Structure of the Program}

Each team of UGA students during both pilot semesters began working with groups of elementary school children enrolled in the afterschool program at its assigned site immediately upon receiving clearance. With monetary support from the OSL, and through supplies and funds gathered through the horticulture department, raised beds were installed at all locations, or in the cases where pre-existing garden structures were already in place, they were checked to determine what was needed to make them ready for planting. The third author was instrumental in making supplies available and in doing some of the necessary preparatory work to get garden beds in place and ready. Each team of students was tasked with creating programs, "lessons," and activities to begin to engage their groups of after-school participants around working in the garden.

During the first two weeks of the semester, the weekly interdisciplinary group discussion meetings were used to ensure that students from all three disciplines had a basic grasp of group dynamics and engaging in group work (facilitated by the social work faculty member) both in terms of their interdisciplinary teams and in terms of facilitating work with the children; basic gardening and horticulture (facilitated by the horticulture faculty member); and a sense of the local food environment, poverty, food insecurity (facilitated by the foods and nutrition faculty member); and social justice, environmental justice, and critical consciousness (facilitated by the social work faculty member). Weekly sessions were then used to troubleshoot, develop skills and techniques, share ideas, grapple with challenges, reflect on the process and the program, and to learn through a transdisciplinary lens. Students wrote weekly reflections based on the particular prompts provided by their instructor. Service-learning occurs for students at the intersection of service and reflection, and serves to enhance what they can offer to their community partners.

\section{Obstacles and Opportunities}

When any one institutional structure engages with another, obstacles and challenges invariably emerge. In the case of the after-school garden program, a number of institutional structures of varying size and scope are involved, creating challenges at multiple system levels. Obstacles also create opportunities for creative engagement, so while challenging, they are not necessarily insurmountable. In the interest of fully presenting the process of program development here, a discussion of obstacles, positive experiences, and opportunities follows. Though the development of this kind of program is bound by context and will vary from place to place, some of the obstacles and opportunities will likely be reflected in others' experiences of attempting to create similar programs. The following discussion offers up one version of an approach to grappling with some of the potential challenges. 


\section{Macro Level: Institutional}

At the university institutional level, a series of structural or logistical challenges exist around creating interdisciplinary learning vehicles, including structures for creating courses themselves and in which department they are technically housed, days and times when other required student courses are scheduled, and procedures for determining teaching assignments, to name a few. In order to address these, the faculty sought support from their respective schools and departments, chose to allot some of their otherwise unscheduled time to creating the program and piloting the course, and continue to advocate for a shift in institutional structures that would make this kind of inter- or transdisciplinary work easier to implement. This continues to be a challenge and one that is likely endemic to many other colleges and universities. For the three involved faculty members, positive experiences have included enhancements in their teaching, both in this particular course and in others. The transdisciplinary nature of this course provided opportunities for faculty to run discussion groups collaboratively with students, garner approaches and methods typically outside their disciplines, and create positive and creative relationships. This positive experience has also contributed to enhancements in research opportunities. However, faculty have and continue to contribute substantial amounts of their time to developing this program and related courses; it is essential to make concrete plans for time management and delegation of responsibilities to support an effort of this scope.

\section{Macro Level: Community/Organization}

At a community/organizational level, a series of different school sites, each with its own administrative structures and housed under the larger mantle of the ACC school system itself, is involved, creating the need to understand many different organizational cultures, foster a variety of professional relationships, and be flexible to accommodate differences. This set of challenges presents opportunities for students to learn firsthand about macro structures and about how they affect direct experiences. This may contribute to how those students approach their work lives upon graduation, and may contribute to their abilities to effectively navigate systems and contribute positively to how those systems function. Some students indicated frustration with the organizational obstacles. For example, students cited concerns about the supplies they used for the garden disappearing and/or being inadequately stored, and having limited access to indoor space when necessary to work with the children. Others expressed frustration with constraints that emerged out of disjointed communication; the absence of a clear chain of communication and shared information often created challenges for the students. However, students in written reflections and inperson discussions expressed a great deal of satisfaction and a seeming sense of self-efficacy when they grappled with these challenges as a team and with faculty, and established ways to address them. As new sites are added we continue to recognize this challenge and have discussions among ourselves and with our students about how best to manage these varied dynamics, and about how to establish relationships that foster effective communication.

\section{Merzo Level}

Some obstacles may present at a mezzo level, meaning among the interdisciplinary teams of students themselves: negotiating time challenges, differences in their disciplines and how they approach learning, and initial ambiguity around their roles in the group. It is through negotiating these challenges that students have the opportunity to maximize their learning and to expand their worldviews. The course instructors put mechanisms into place to help students foster functional group dynamics and to negotiate conflict if or when it arises. Within the first two weeks of the semester, the social work faculty member facilitated a workshop for the students focused on group development, group dynamics, and cohesion. Students were asked to apply principles learned not only to the groups they would be developing among the children, but to their own interdisciplinary task groups. Throughout the semester, students referred back to some of these principles in their evolving written reflections and in-person discussions around both their task groups and the 
groups they established with the children. They had a common glossary of terms and ideas to apply that appeared to facilitate effective negotiation of challenges. Also, students referred to how much they learned from and with each other, and how their respective roles became increasingly clear over the course of their semester working together.

\section{Opportunities}

While there are a number of challenges to be expected in creating a program that incorporates so many stakeholders, there is an equally expansive potential for successes. Based on the first complete semester pilot and an almost complete second semester pilot, initial process evaluations suggest that stated student learning objectives across disciplines appear to be well met for all participants, based on their written reflections and in-person discussions. Students met objectives in their respective disciplines, but their overall learning was enhanced substantially by the interdisciplinary structure of the service itself and of the discussion groups. Students grew in terms of disciplinary content knowledge, but even more so in terms of their process knowledge derived through both the interdisciplinary collaboration and the exposure to and work with the children in their groups and with community stakeholders. Students from each discipline learned from the others in terms of ideas and approaches, and also learned a great deal about how different perspectives serve to complement each other and create opportunities for broader, sustainable impact. Finally, in addition to the stated or intended objectives, students made outstanding contributions to the development of the program and the course itself. Through the opportunity to contribute to the development of both, students' level of commitment seemed to increase and their sense of self-efficacy, empowerment, and awareness of how to build relationships and programs appeared to grow as well.

While future research will provide a more systematic understanding of the efficacy of the program and its outcomes, anecdotally it appears that some benefits to community partners (the after-school sites involved) have also emerged. There appear to be direct benefits to the children who have participated related to food and nutrition awareness, relationship to gardening and sustainable food production, relationship to nature, and self-efficacy. Early on in the semester, one team of UGA students engaged their child participants in an exercise around identifying their favorite fruits and vegetables. During this activity one child asked, "are Twizzlers a fruit"? The UGA students reported "shock" when they heard this, along with having an "epiphany" about the potential distortion of knowledge around where food comes from. This event provided opportunities for the UGA students to challenge themselves to respond in a way that helped the child to expand her understanding of where food comes from, and challenged them to become much more critically conscious about the children and their access to and awareness about nutritional food. Over the course of the semester, UGA students also created opportunities for the children to sample fruits and vegetables, some picked directly from the gardens they were growing, and others purchased because the season sometimes created lags in access to their own harvest. Children responded cautiously at first when invited to try "strange" or "weird" fruits and vegetables. Over the course of the semester, they clamored for tastings and cooking demonstrations and were willing to try everything offered, from carrots to radishes to spinach (which they'd pick right out of the ground and eat with gusto), to collard greens, to name a few. Benefits to the schools beyond those directly related to the children are also emerging: participating sites now have functioning gardens, and in all cases those gardens are active and tended to; they have new afterschool resources upon which to rely in terms of people and activities; and the foundation has been laid for more systematic programming and resource allocation.

Participating faculty have benefitted substantially through the power of collaboration; what one person could not have accomplished single-handedly, three have managed to accomplish fairly quickly. This is not to say the program is developed fully and that there is not a great deal more work to be done, but it is to say that the strength that emerges out of positively driven collaborative efforts is not to be underestimated. The three faculty have plans for continued collaboration in 
terms of further program development, teaching, and inter-disciplinary research. Targets for further developing the program include installing a functional school garden at all public schools in ACC, and at community organizations that provide afterschool programming to children whose schools do not offer it. With an expanded program there are plans to build a curriculum and create additional service-learning opportunities for students in the currently participating disciplines, and to add opportunities for students in other disciplines. Additional plans involve the systematic inclusion of community members in support of the school garden effort, including intergenerational mentoring. Specific plans for future research include quantitative and qualitative data collection to explore UGA student learning experiences and outcomes; child knowledge, and social and behavioral changes; parent knowledge, attitude, and food behavior outcomes; and school administrator perceptions of organizational outcomes.

\section{Plans for Future Research}

Because of the interdisciplinary nature of this program, plans for evaluating outcomes are also interdisciplinary. One of the gaps in the extant body of literature related to school gardens resonates around psychosocial outcomes for individual participants and also for family and community. As this program develops further, plans for research include measurement of UGA student learning outcomes as noted above. Students who participate in the program will complete pre- and post- surveys that include Likert-type questions as well as open-ended questions designed to assess any changes in their interests, knowledge, values, and perspectives. Additional plans for research focus on health and nutrition outcomes for child participants (e.g., preference for fruit and vegetables); psychosocial outcomes for child participants, including relationship to nature and sense of selfefficacy (among other outcomes); community outcomes, including a focus on collective efficacy; and outcomes for the after-school programs, including degree to which the program offset resource issues, enhanced overall after-school programming, affected a shift in the culture of the organizational environment, and contributed to change in relationship between the program and the community.

As UGA continues to serve its land-grant mission and accommodates to inventive forms of community engagement, more and more efforts are being made to incorporate and support ecologically sustainable approaches. This ethos creates space for innovative work that transcends a variety of boundaries, including those between disciplines and structures and those between university and community. The after-school garden program embraces this notion of transcending those boundaries to optimize strengths and resources, and to contribute to creative efforts to address food insecurity and community empowerment.

\section{References}

Anderson, S. A. (1990). Core indicators of nutritional state for difficult-to-sample populations. Journal of Nutrition, 120, 1559-1600.

Blair, D. (2009). The child in the garden: An evaluative review of the benefits of school gardening. The Journal of Environmental Education, 40(2), 15-38. http://dx.doi.org/10.3200/JOEE.40.2.15-38

Dirks, A. E., \& Orvis, K. (2005). An evaluation of the junior master gardener program in third grade classrooms. HortTechnology, 15, 443-447.

Eyler, J. S., Giles, D. E., Jr., Stenson, C. M., \& Gray, C. J. (2003). At a glance: What we know about the effects of service-learning on college students, faculty, institutions, and communities, 1993-2000, third edition. In Campus Compact, Introduction to service-learning toolkit: Readings and resources for faculty (2nd ed.) (pp. 15-19). Providence, Rhode Island: Campus Compact.

Feeding America. (2010). Hunger study 2010. Retrieved from http:// feedingamerica.org/hunger-inamerica/hunger-studies/hunger-study-2010.aspx

Food Bank of Northeast Georgia. (2010). Food for thought: 2010 annual report. Athens, Georgia: Author.

Gelmon, S. B. (2000). How do we know that our work makes a difference? Assessment strategies for service-learning and civic engagement. Metropolitan Universities: An International Forum, 11(2), 28-39.

Georgia Department of Labor. (n.d.). Area unemployment rate and labor force estimates. Retrieved November 3, 2011, from http://www.dol.state.ga.us/pr/laborforce.htm 
Graham, H., Feenstra, G., Evans, A. M., \&ZidenbergCherr, S. (2004). Davis school program supports life-long healthy eating habits in children. California Agriculture, 58, 200-205. http://dx.doi.org/10.3733/ca.v058n04p200

Hollander, E. (1998). Picturing the engaged campus. In M. Rothman (Ed.), Service matters. Providence, Rhode Island: Campus Compact.

Jones, S. (2003). Introduction to the second edition. In Campus Contact, Introduction to service-learning toolkit: Readings and resources for faculty (2nd ed.) (pp. 1-4). Providence, Rhode Island: Campus Compact.

Klemmer, C. D., Waliczek, T. M., \& Zajicek, J. M. (2005). Growing minds: The effect of a school gardening program on the science achievement of elementary students. HortTechnology, 15, 448-452.

Lee, J. S., Bender, A., Kurtz, H. E., \& Kim, H. H. (In press). Analyzing food store survey data using Geographic Information Systems (GIS). In American Dietetic Association, Hunger and Environmental Nutrition and Dietetic Educators of Practitioners practice groups (Eds.), Teaching food systems and sustainability in nutrition education and dietetic training: Lessons for educators.

Lineberger, S. E., \&Zajicek, J. M. (2000). School gardens: Can a hands-on teaching tool affect students' attitudes and behaviors regarding fruits and vegetables? HortTechnology, 10, 593-597.

Mabie, R., \& Baker, M. (1996). The influence of experiential instruction on urban elementary students' knowledge of the food and fiber system. Journal of Extension, 34(96), 1-4.

McAleese, J. D., \& Rankin, L. L. (2007). Garden-based nutrition education affects fruit and vegetable consumption in sixth-grade adolescents. Journal of the American Dietetic Association, 107, 662-665. http://dx.doi.org/10.1016/j.jada.2007.01.015

Matthews, P. (2011, January 7). UGA recognized for community engagement by Carnegie Foundation [Web log post]. Retrieved from http://www.servicelearning.uga.edu/blog/2011/01 /07/uga-recognized-for-community-engagementby-carnegie-foundation/

Mergen, B. (2003). Review essay: Children and nature in history. Environmental History, 8, 643-669. http://dx.doi.org/10.2307/3985888
Moore, R. (1995). Growing foods for growing minds: Integrating gardening and nutrition education into the total curriculum. Children's Environments, 12(2), 134-142.

Morris, J. L., Briggs, M., \&Zidenberg-Cherr, S. (2000). School-based gardens can teach kids healthier eating habits. California Agriculture, 54(5), 40-46. http://dx.doi.org/10.3733/ca.v054n05p40

Morris, J. L., \&Zidenberg-Cherr, S. (2002). Gardenenhanced nutrition education curriculum improves fourth-grade school children's knowledge of nutrition and preferences for some vegetables. Journal of the American Dietetic Association, 102(1), 91-93. http://dx.doi.org/10.1016/S00028223(02)90027-1

Office of Public Affairs, University of Georgia. (n.d. a). History of UGA. Retrieved November 1, 2011, from http://www.uga.edu/profile/history

Office of Public Affairs, University of Georgia. (n.d. b). The mission of the University of Georgia. Retrieved November 1, 2011, from http://www.uga.edu/profile/mission/

Office of Public Affairs, University of Georgia (n.d. c). UGA by the numbers. Retrieved November 1, 2011, from http://www.uga.edu/profile/facts/

Parmer, S. M., Salisbury-Glennon, J., Shannon, D., \&Struempler, B. (2009). School gardens: An experiential learning approach for a nutrition education program to increase fruit and vegetable knowledge, preference, and consumption among second-grade students. Journal of Nutrition Education and Behavior, 41, 212-217. http://dx.doi.org/10.1016/j.jneb.2008.06.002

Phillips, A. (2007). Service learning and social work education: A natural but tenuous connection. In M. Nadel, V. Majewski, \& M. Sullivan-Cosetti (Eds.), Social work and service learning: Partnerships for social justice (pp. 3-19). Lanham, Maryland: Rowan \& Littlefield.

Rahm, J. (2002). Emergent learning opportunities in an inner-city youth gardening program. Journal of Research in Science Teaching, 39, 164-184. http://dx.doi.org/10.1002/tea.10015

Smith, L. L., \&Mostenbocker, C. E. (2005).Impact of hands-on science through school gardening in Louisiana public elementary schools. HortTechnology, 15, 439-443. 
U.S. Census Bureau. (n.d.). America FactFinder. Retrieved October 4, 2011, from http:/ / factfinder2.census. gov/faces/nav/jsf/pages/searchresults.xhtml? ref=geo\&refresh $=\mathrm{t}$

U.S. Department of Agriculture. (n.d. a). Your food environment atlas. Retrieved November 3, 2011, from http://www.ers.usda.gov/foodatlas/

U.S. Department of Agriculture. (n.d. b). Food desert locator. Retrieved November 3, 2011, from http://www.ers.usda.gov/data/fooddesert/
U.S. Department of Agriculture, Agriculture Marketing Service. (n.d.). Food Deserts. Retrieved from http://apps.ams.usda.gov/fooddeserts/foodDesert $\underline{\text { s.aspx }}$

Vernon, A. \& Ward, K. (1999). Campus and community partnerships: Assessing impacts andstrengthening connections. Michigan Journal of Community Service Learning, 6(1), 30-37.

http://hdl.handle.net/2027/spo.3239521.0006.103 


\section{Table 1. Logic Model for the After-School Garden Program in Athens-Clarke County, Georgia (ACC)}

Situation: With rising food prices and economic recessions, food-insecure ACC residents, especially children, will face continued challenges around having consistent and dependable access to enough food for active and healthy living. The need is becoming increasingly urgent to identify sustainable, empowering strategies to increase access to healthy foods for people at all income levels.

\begin{tabular}{|c|c|c|c|c|c|}
\hline & & & \multicolumn{3}{|c|}{ Outcomes } \\
\hline Inputs & Activities & Outputs & Initial & Intermediate & Longer Term \\
\hline $\begin{array}{l}\text { Materials, resources, } \\
\text { personnel - what is } \\
\text { needed to develop and } \\
\text { run the program }\end{array}$ & $\begin{array}{l}\text { What the program does to } \\
\text { fulfill its mission - what is } \\
\text { done }\end{array}$ & $\begin{array}{l}\text { Direct products of the } \\
\text { activities - what is } \\
\text { received }\end{array}$ & $\begin{array}{l}\text { Changes in participants } \\
\text { that are a direct, } \\
\text { immediate result of } \\
\text { participation in the } \\
\text { program }\end{array}$ & $\begin{array}{l}\text { Changes in participants } \\
\text { that occur as a result of } \\
\text { initial outcomes }\end{array}$ & $\begin{array}{l}\text { Changes in participants } \\
\text { that can only be assessed } \\
\text { after some time has } \\
\text { passed }\end{array}$ \\
\hline $\begin{array}{l}\text { - Schools with after- } \\
\text { school programs and } \\
\text { willingness to } \\
\text { participate } \\
\text { - School gardens or } \\
\text { outdoor space to build } \\
\text { garden structures } \\
\text { - Gardening supplies and } \\
\text { tools } \\
\text { - Nutrition education } \\
\text { materials } \\
\text { - Other supplies for after- } \\
\text { school activities } \\
\text { - Transportation to } \\
\text { schools } \\
\text { - Some funding or } \\
\text { potential for funding }\end{array}$ & $\begin{array}{l}\text { - Faculty establishes } \\
\text { contact with schools } \\
\text { - Faculty establishes the } \\
\text { program site } \\
\text { - Faculty recruit UGA } \\
\text { students from involved } \\
\text { departments } \\
\text { - Faculty and students } \\
\text { develop the content } \\
\text { and structure of } \\
\text { interdisciplinary after- } \\
\text { school program } \\
\text { activities focused on } \\
\text { gardening and nutrition } \\
\text { - UGA students carry out } \\
\text { the program } \\
\text { - Faculty and UGA } \\
\text { students evaluate the }\end{array}$ & $\begin{array}{l}\text { - Total number of } \\
\text { participating UGA } \\
\text { students } \\
\text { - Total number of } \\
\text { participating schools } \\
\text { - Total number of after- } \\
\text { school program } \\
\text { participants across the } \\
\text { semester } \\
\text { - Types of content and } \\
\text { structure of after-school } \\
\text { program activities } \\
\text { - Total number of } \\
\text { activities used } \\
\text { - Quantity and quality of } \\
\text { contact and interaction } \\
\text { among UGA students, } \\
\text { after-school program }\end{array}$ & $\begin{array}{l}\text { - Increase in the number } \\
\text { of participating schools, } \\
\text { after-school } \\
\text { participants, and UGA } \\
\text { students } \\
\text { - Improved content and } \\
\text { structure of after-school } \\
\text { program activities } \\
\text { - Increased quantity and } \\
\text { quality of contact and } \\
\text { interaction among UGA } \\
\text { students, after-school } \\
\text { program participants, } \\
\text { school administrators, } \\
\text { and parents } \\
\text { - Increase in the }\end{array}$ & $\begin{array}{l}\text { - Increase in the number } \\
\text { of participating schools, } \\
\text { after-school } \\
\text { participants, and UGA } \\
\text { students } \\
\text { - Improved content and } \\
\text { structure of after-school } \\
\text { program activities } \\
\text { - Increased quantity and } \\
\text { quality of contact and } \\
\text { interaction among UGA } \\
\text { students, after-school } \\
\text { program participants, } \\
\text { school administrators, } \\
\text { and parents } \\
\end{array}$ & $\begin{array}{l}\text { - Maintenance of the } \\
\text { number of participating } \\
\text { schools, after-school } \\
\text { participants, and UGA } \\
\text { students } \\
\text { - Maintenance of the } \\
\text { content and structure of } \\
\text { after-school program } \\
\text { activities } \\
\text { - Maintenance of the } \\
\text { quantity and quality of } \\
\text { contact and interaction } \\
\text { among UGA students, } \\
\text { after-school program } \\
\text { participants, school } \\
\text { administrators, and } \\
\text { parents and community }\end{array}$ \\
\hline $\begin{array}{l}\text { - UGA students from } \\
\text { involved departments } \\
\text { - Faculty advisors } \\
\text { - School administrators } \\
\text { - After-school } \\
\text { coordinators in the }\end{array}$ & $\begin{array}{l}\text { process and outcome of } \\
\text { the program } \\
\text { - After-school program } \\
\text { participants learn about } \\
\text { food systems, }\end{array}$ & $\begin{array}{l}\text { participants, school } \\
\text { administrators, and } \\
\text { parents } \\
\end{array}$ & $\begin{array}{l}\text { and attitudes of food } \\
\text { systems, gardening, } \\
\text { food, nutrition, } \\
\text { sustainability, and self- } \\
\text { efficacy among } \\
\text { participating UGA }\end{array}$ & $\begin{array}{l}\text { and, attitudes of food } \\
\text { systems, gardening, } \\
\text { food, nutrition, } \\
\text { sustainability, and self- } \\
\text { efficacy among } \\
\text { participating UGA }\end{array}$ & $\begin{array}{l}\text { - Maintenance of the } \\
\text { awareness, knowledge } \\
\text { and, attitudes of food } \\
\text { systems, gardening, } \\
\text { food, nutrition, } \\
\text { sustainability, and self- }\end{array}$ \\
\hline
\end{tabular}




\begin{tabular}{|c|c|c|c|c|c|}
\hline & & & \multicolumn{3}{|c|}{ Outcomes } \\
\hline Inputs & Activities & Outputs & Initial & Intermediate & Longer Term \\
\hline $\begin{array}{l}\text { schools } \\
\text { - Parent-Teacher } \\
\text { Organizations (PTOs) } \\
\text { - UGA Office of Service } \\
\text { Learning (OSL) } \\
\\
\text { - After-school program } \\
\text { participants }\end{array}$ & $\begin{array}{l}\text { gardening, food, } \\
\text { nutrition, sustainability, } \\
\text { and self-efficacy } \\
\text { - Parents and community } \\
\text { are invited to } \\
\text { participate through } \\
\text { evening programming }\end{array}$ & $\begin{array}{l}\text { and belief about } \\
\text { environment, } \\
\text { gardening, food, } \\
\text { nutrition, sustainability, } \\
\text { and self-efficacy among } \\
\text { participating UGA } \\
\text { students, after-school } \\
\text { participants, school } \\
\text { administrators, and } \\
\text { parents and community }\end{array}$ & $\begin{array}{l}\text { students, after-school } \\
\text { participants, school } \\
\text { administrator, and } \\
\text { parents and community } \\
\text { - Identify sustainable, } \\
\text { empowering strategies } \\
\text { to increase access to } \\
\text { healthy foods in ACC }\end{array}$ & $\begin{array}{l}\text { students, after-school } \\
\text { participants, school } \\
\text { administrator, and } \\
\text { parents and community } \\
\text { - Develop sustainable, } \\
\text { empowering strategies } \\
\text { to increase access to } \\
\text { healthy foods in ACC }\end{array}$ & $\begin{array}{l}\text { efficacy among } \\
\text { participating UGA } \\
\text { students, after-school } \\
\text { participants, school } \\
\text { administrator, and } \\
\text { parents and the } \\
\text { community } \\
\text { - Maintenance of } \\
\text { sustainable, } \\
\text { empowering strategies } \\
\text { to increase access to } \\
\text { healthy foods in ACC. }\end{array}$ \\
\hline
\end{tabular}

